Jurnal Keperawatan Silampari

Volume 3, Nomor 1, Desember 2019

e-ISSN: 2581-1975

p-ISSN: 2597-7482

DOI: https://doi.org/10.31539/jks.v3i1.513

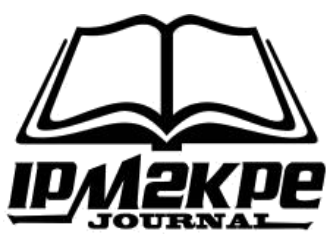

\title{
PERBANDINGAN TINDAKAN MASSAGE COUNTERPRESSURE DAN PEMBERIAN DARK CHOCOLATE TERHADAP PENURUNAN NYERI HAID (DISMENOREA)
}

\author{
Rindang Fitriana Ulfa ${ }^{1}$, Agus Suwandono ${ }^{2}$, Kamilah Budhi ${ }^{3}$ \\ Jurusan Kebidanan Magister Terapan Kesehatan, Poltekkes Kemenkes Semarang ${ }^{1,2,3}$ \\ Rindang.FitrianaUlfa1992@Gmail.com ${ }^{1}$
}

\begin{abstract}
ABSTRAK
Tujuan penelitian ini adalah untuk melihat perbandingan pemberian tindakan massage counterpressure dan pemberian dark chocolate terhadap penurunan nyeri haid (dismenorea). Desain menggunakan quasi eksperimen dengan rancangan two group comparison pretest and posttest with control group design. Hasil penelitian menunjukkan bahwa pada kelompok dark chocolate dan obat anti nyeri, massage counterressure dan obat anti nyeri diperoleh $\rho$ value 0,000 . Terdapat perbedaan yang signifikan sebelum dan sesudah pemberian tindakan. Hasil uji man whitney didapatkan ada perbedaan antara 2 kelompok dengan nilai $\rho$ value 0,000 . Simpulan, ada perbedaan pengaruh antara kelompok dark chocolate dan kelompok massage counterpressure terhadap intensitas nyeri haid. Pemberian dark chocolate 100 gram selama 2 hari dan obat anti nyeri lebih efektif dibandingkan tindakan massage counterpressure 20 menit selama 2 hari dan obat anti nyeri terhadap intensitas nyeri haid.
\end{abstract}

Kata Kunci: Dark Chocolate, Massage Counterpressure, Nyeri Haid

\section{ABSTRACT}

The purpose of this study was to see the comparison between the administration of Massage Counterpressure and the provision of dark chocolate to reduce menstrual pain (dysmenorrhoea). The design uses a quasi-experimental design with two groups of pretest and posttest with control group design. The results showed that in the dark chocolate and anti-pain medication group, massage counterressure and anti-pain medicine obtained $\rho$ value of 0,000. there are significant differences before and after the administration of action. The results of the man whitney test found that there were differences between the 2 groups with a value of $\rho$ value of 0,000. Conclusion, there is a difference of influence between the dark chocolate group and the counterpressure massage group on the intensity of menstrual pain. Giving 100 grams of dark chocolate for 2 days and anti-pain medication is more effective than a 20-minute counterpressure massage for 2 days and anti-pain medication for menstrual pain intensity.

Keywords: Dark Chocolate, Massage Counterprssure, Menstrual Pain 


\section{PENDAHULUAN}

Dismenorea adalah nyeri yang dialami selama haid yang disebabkan meningkatnya prostaglandin dan adanya pengaruh psikologis seperti stress dan cemas. Menstruasi merupakan proses pelepasan dinding rahim yang disertai dengan perdarahan yang terjadi secara berulang setiap bulan, kecuali pada saat terjadi kehamilan. Hari pertama terjadinya menstruasi dihitung sebagai awal setiap siklus mentruasi (hari ke-1). Menstruasi akan terjadi 3-7 hari. Hari terakhir menstruasi adalah waktu berakhir sebelum mulai siklus menstruasi berikutnya. Rata-rata perempuan mengalami siklus menstruasi selama 21-40 hari. Hanya sekitar $15 \%$ perempuan yang mengalami siklus menstruasi selama 28 hari dismenorea menjadi alasan umum bagi remaja maupun berbagai tingkat usia mengunjungi dokter ginekolog atau pelayanan kesehatan terdekat (Abdul Hanan \& Sindarti, 2015). Prevalensi kejadian dismenorea di dunia sekitar 50$70 \%$ terutama di tahun pertama mengalami haid. Menurut WHO data kejadian 1.769.425 jiwa (90\%) wanita yang mengalami dismenorea $10-15 \%$ diantaranya mengalami dismenorea berat. Lebih $50 \%$ wanita di setiap negara mengalami nyeri haid. Di Amerika sekitar 60\%, di Swedia sekitar 72\% dan di Indonesia diperkirakan 55\% (Azima, Bakhshayesh, Kaviani, Abbasnia dan Sayadi, 2015). Banyak wanita yang membeli obat sendiri dan tidak berkunjung ke dokter. Nyeri haid juga bertanggung jawab atas ketidakhadiran saat bekerja dan sekolah, sebanyak 13-51\% wanita telah absen sedikitnya sekali dan 5-14\% berulang kali absen.

Salah satu terapi non farmakologis dari segi gizi yang dapat dijadikan alternatif yaitu dark chocolate (coklat hitam) kaya akan kalsium, kalium, natrium, magnesium serta vitamin A, B1, C, D, dan E, Magnesium berguna untuk merelaksasikan otot dan dapat memberikan rasa rileks yang dapat mengendalikan suasana hati yang murung juga berfungsi memperbesar pembuluh darah sehingga mencegah kejang otot dan dinding pembuluh darah (Abdul Hanan \& Sindarti, 2015). Susilawati (2009) menyatakan bahwa pemberian coklat lebih efektif digunakan sebagai terapi non farmakologis untuk meredakan nyeri haid dibandingkan pemberian susu sapi, yang mudah didapatkan tetapi kurang disukai kurang menyukai susu sapi karena rasanya yang kurang manis.

Terapi lain dismenorea yaitu massage counterpressure, yang bertujuan untuk mengurangi rasa nyeri secara alamiah. Pemberian massage counterpressure pada daerah lumbal dapat menstimulasi serabut taktil di kulit sehingga sinyal nyeri haid dapat di hambat. Counterpressure menyebabkan peningkatan endorphine, meredakan sakit secara alami, merupakan massage atau memijat dengan tekanan kuat yaitu meletakkan tangan atau bagian datar dari tangan, atau dapat menggunakan bola tenis. Counterpressure dapat diberikan dengan gerakan lurus atau lingkaran kecil yangdapat menutup gerbang pesan nyeri yang akan dihantar menuju medulla spinalis dan otak, yang dapat menyebabkan penurunan intensitas nyeri (Deasyana, Pratiwi \& Wagiyo, 2015). Penelitian di Kabupaten Demak (2017) menyatakan bahwa massage counterpressure lebih efektif dalam penurunan nyeri dari pada kompres hangat ini dikarenakan sistem kerjanya langsung memblokir pesan nyeri yang akan dihantarkan menuju medulla spinalis dan otak, sedangkan kompres hangat sistem kerjanya mempertahankan komponen sistem vaskuler dalam keadaan vasodilatasi menjadi homeostatis, mencegah terjadinya spasme otot, serta dapat menurunkan kecemasan serta adaptasi dengan nyeri, proses ini akan lebih lama dalam penurunan nyerinya dibanding tehnik counterpressure. 


\section{METODE PENELITIAN}

\section{Desain Penelitian}

Penelitian sekarang menggunakan rancangan quasi ekprimen dengan pre test and post test with control.

\section{Populasi dan Sample Penelitian}

Populasi dalam penelitian ini adalah mahasiswa Akbid Harapan Mulya Ponorogo yang berusia, remaja akhir usia 18-21 tahun. Teknik pengambilan sampel menggunakan teknik non probability sampling, yaitu purposive sampling dengan pemilihan sampel yang dilakukan berdasarkan maksud dan tujuan tertentu yang ditentukan oleh peneliti. Pertimbangan dalam pemilihan sampel yang dilakukan peneliti adalah dengan menentukan kriteria yang terdiri dari kriteria inklusi dan eksklusi.

\section{Kriteria Inklusi \& Eksklusi}

Pada penelitian ini kriteria inklusi sampel penelitian yaitu; 1) Remaja akhir yang mengalami dismenorea primer umur 18-21 tahun; 2) Bersedia untuk tidak menggunakan terapi jenis apapun selain terapi yang diberikan peneliti; 3) Belum pernah menikah dan melahirkan; 4) Bersedia menjadi responden adapun kriteria eksklusi pada penelitian ini yaitu klien yang terdiagnosa penyakit ginekologis tertentu (kista, tumor, dan endometriosis).

\section{Instrument Penelitian}

Instrument yang digunakan untuk pengumpulan data, yaitu kuesioner pengukur intensitas nyeri. Sedangkan lama menstruasi dan riwayat dismenorea sebelumnya menggunakan format isian pengambilan data. Pengukuran intensitas nyeri dilakukan dengan menggunakan numerik VAS (visual analog scale). Numerik VAS merupakan skala analog visual dengan dengan menggunakan skala numerik. Skala ini merupakan alat ukur yang diigunakan untuk mengukur intensitas nyeri. Ujung sebelah kiri menggambarkan kondisi tidak dirasakan nyeri dan ujung sebelah kanan menggambarkan intensitas nyeri yang amat berat. Mekanisme pengukuran dengan VAS (visual analog scale), yaitu responden diminta untuk menandai salah satu titik pada grafik garis yang dianggap mendekati atau menggambarkan intensitas nyeri yang dirasakan pada saat pengukuran. Alat ukut ini merupakan skala yang mudah digunakan dan mudah dalam menginterpretasikannya.

\section{Prosedur dan Alur Penelitian}

Dibantu enumerator, dengan kriteria bidan. Sebelum dilakukan pengumpulan data dilakukan persemaan persepsi dan pelatihan prosedur penelitian dan pelaksanaan penelitian. Dibantu enumerator melakukan pemeriksaan fisik untuk mengetahui keadaan responden, apakah memenuhi kritesia atau tidak responden yang memenuhi criteria selanjutya dierikan cokelat pada kelompok 1 dengan jenis dark chocolate batangan dan tambahan obat anti nyeri. Melakukan massage counterpressure pada kelompok 2 dan diberikan obat anti nyeri. Memberikan obat anti nyeri ke kelompok kontrol. Perlakuan dilakukan 2 hari kepada responden yang mengalami nyeri haid. Diberikan kuesioner setelah perlakuan untuk menilai tingkat nyeri. 


\section{HASIL PENELITIAN}

\section{Analisis Variabel Counfonding}

Digunakan untuk menggambarkan sebelum dilakukan intervensi pada kelompok pemberian dan obat anti nyeri dan pada kelompok tindakan massage counterpressure dan obat anti nyeri, kedua kelompok berada pada kondisi setara atau tidak berada jauh dalam hal persebaran umur, lama menstruasi, dan kebiasaan minum obat anti nyeri haid, sehingga dapat mencerminkan pengaruh masing-masing intervensi sehingga terjadinya penurunan intensitas nyeri haid.

\section{Karakteristik Responden}

Tabel. 1

Hasil Uji Karakteristik Responden pada Kelompok Intervensi Pemberian Dark Chocolate dan Kelompok Tindakan Massage Counterpressure

\begin{tabular}{|c|c|c|c|c|}
\hline \multirow[b]{2}{*}{ Variabel } & \multicolumn{3}{|c|}{ Kelompok } & \multirow[b]{2}{*}{$\begin{array}{c}p \\
\text { value }\end{array}$} \\
\hline & $\begin{array}{c}\text { Dark Chocolate } \\
(\mathrm{n}=16)\end{array}$ & $\begin{array}{c}\text { Massage } \\
\text { counterpressure }(n=16)\end{array}$ & $\begin{array}{c}\text { Kelompok } \\
\text { Kontrol }(n=16)\end{array}$ & \\
\hline \multicolumn{5}{|c|}{ 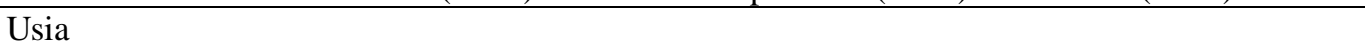 } \\
\hline Mean (SD) & $19,88(0,957)$ & $19,19(0,834)$ & $19,38(1,025)$ & \multirow{3}{*}{0,140} \\
\hline Median & 20 & 19 & 19 & \\
\hline Min-Maks & $18 \pm 21$ & $18 \pm 20$ & $18 \pm 21$ & \\
\hline \multicolumn{5}{|l|}{ Lama Menstruasi } \\
\hline \multicolumn{5}{|l|}{ Mean (SD) } \\
\hline Median & $7,00(0,533)$ & $6,81(0,696)$ & $6,94(0,854)$ & \multirow[t]{3}{*}{0,776} \\
\hline \multirow[t]{2}{*}{ Min-Maks } & 7 & 7 & 7 & \\
\hline & $6 \pm 8$ & $6 \pm 8$ & $6 \pm 8$ & \\
\hline \multicolumn{5}{|l|}{ Kebiasaan Minum } \\
\hline Obat & & & & \multirow{3}{*}{0,564} \\
\hline Ya & $50,0 \%$ & $50,0 \%$ & $62,5 \%$ & \\
\hline Tidak & $50,0 \%$ & $50,0 \%$ & $37,5 \%$ & \\
\hline
\end{tabular}

Berdasarkan tabel 1 di atas terlihat bahwa rata-rata usia responden pada kelompok pemberian dark chocolate dan obat anti nyeri adalah 19,88 tahun, dan pada kelompok tindakan massage counterpressure dan obat anti nyeri rata-rata usia responden adalah 19,19 tahun. Sedangkan pada kelompok kontrol rata-rata usia responden adalah 19,38 tahun. Berdasarkan hasil uji statistik kruskal wallis didapatkan nilai $p$ value sebesar 0,140 maka dapat disimpulkan bahwa tidak terdapat perbedaan yang signifikan rata-rata usia responden diantara tiga kelompok perlakuan $(p>0,05)$. Sehingga faktor usia dalam penelitian ini dapat dikendalikan.

Rata-rata lama menstruasi responden pada kelompok pemberian dark chocolate dan obat anti nyeri adalah 7 hari, dan pada kelompok tindakan massage counterpressure dan obat anti nyeri rata-rata lama menstruasi responden adalah 6,81 hari. Sedangkan pada kelompok kontrol rata-rata lama menstruasi responden adalah 6,94 hari. Berdasarkan hasil uji statistik kruskal wallis didapatkan nilai $p$ value sebesar 0,776 maka dapat disimpulkan bahwa tidak terdapat perbedaan yang signifikan rata-rata lama menstruasi responden diantara dua kelompok perlakuan $(p>0,05)$. Sehingga faktor lama menstruasi dalam penelitian ini dapat dikendalikan.

Kebiasaan minum obat pada saat nyeri haid pada kelompok pemberian dark chocolate dan obat anti nyeri sebanyak 50\% responden, dan terdapat $50 \%$ responden yang tidak minum obat pada saat nyeri haid. Pada kelompok tindakan massage 
counterpressure dan obat anti nyeri sebanyak $50 \%$ responden terbiasa minum obat pada saat nyeri haid dan terdapat $40 \%$ responden yang tidak minum obat pada saat nyeri haid. Sedangkan pada kelompok control sebanyak $62,5 \%$ responden terbiasa minum obat pada saat nyeri haid dan terdapat $37,5 \%$ responden yang tidak minum obat pada saat nyeri haid. Berdasarkan hasil uji statistik chi-square test didapatkan nilai $p$ value sebesar 0,564 maka dapat disimpulkan bahwa tidak terdapat perbedaan yang signifikan rata-rata kebiasaan minum obat responden pada saat nyeri haid diantara dua kelompok perlakuan $(p>0,05)$. Sehingga faktor kebiasaan minum obat dalam penelitian ini dapat dikendalikan.

Berdasarkan hasil tersebut menunjukkan bahwa pada saat sebelum perlakuan, ketiga kelompok dark chocolate dan obat anti nyeri, massage counterpressure dan obat anti nyeri, dan kelompok kontrol (obat anti nyeri) dalam kondisi yang tidak berbeda jauh atau setara dalam hal usia, lama menstruasi, dan kebiasaan minum obat, sehingga intensitas nyeri haid setelah pemberian dark chocolate dan obat anti nyeri dan tindakan Massage counterpressure dan obat anti nyeri pada kedua kelompok dapat mencerminkan pengaruh yang diberikan oleh masing-masing metode sehinga terjadinya penurunan intensitas nyeri haid atau dismenorea merupakan dari efek pemberian dark chocolate dan obat anti nyeri dan tindakan massage counterpressure dan obat anti nyeri.

\section{Hasil Analisis Bivariat}

\section{Penurunan Nyeri Haid (Dismenorea) pada Kelompok Intervensi Pemberian Dark Chocolate Dibandingkan dengan Kelompok Kontrol}

Tabel. 2

Penurunan Nyeri Haid Pada Intervensi Pemberian Dark Chocolate

Dibandingkan Dengan Kelompok Kontrol

\begin{tabular}{|c|c|c|c|c|}
\hline \multirow{2}{*}{$\begin{array}{c}\mathrm{N} \\
\mathrm{O}\end{array}$} & \multirow{2}{*}{$\begin{array}{c}\text { Variabel Nyeri } \\
\text { Haid }\end{array}$} & \multicolumn{2}{|c|}{ Kelompok } & \multirow[t]{2}{*}{$p$ value $^{1}$} \\
\hline & & $\begin{array}{c}\text { Dark } \\
\text { Chocolate }(\mathrm{n}=16)\end{array}$ & $\begin{array}{l}\text { Kelompok Kontrol } \\
(\mathrm{n}=16)\end{array}$ & \\
\hline \multirow[t]{5}{*}{1.} & Sebelum & & & \\
\hline & Perlakuan & & & \\
\hline & a. Mean \pm SD & $4,81(0,655)$ & $4,50(0,516)$ & 0,239 \\
\hline & b. Min-Maks & $4 \pm 6$ & $4 \pm 5$ & \\
\hline & c. Median & 5 & 4,5 & \\
\hline \multirow[t]{5}{*}{2.} & Setelah & & & \\
\hline & Perlakuan & & & \\
\hline & a. Mean $\pm \mathrm{SD}$ & $1,56(0,512)$ & $3,12(0,806)$ & 0,000 \\
\hline & b. Min-Maks & $1 \pm 2$ & $2 \pm 4$ & \\
\hline & c. Median & 2 & 3 & \\
\hline \multirow[t]{2}{*}{3.} & $\begin{array}{l}\text { Perbedaan } \\
\text { nyeri haid } \\
\text { sebelum dan } \\
\text { sesudah } \\
\text { perlakuan }\end{array}$ & & & \\
\hline & $p$ value $^{2}$ & 0,000 & 0,001 & - \\
\hline \multirow[t]{4}{*}{4.} & Rerata Selisih & & & \\
\hline & a. Mean \pm SD & $3,25 \pm 0,775$ & $1,38 \pm 0,719$ & 0,000 \\
\hline & b. Min-Maks & $2-4$ & $0-2$ & 0,000 \\
\hline & c. Median & 3 & 1,5 & \\
\hline
\end{tabular}


Berdasarkan tabel 2 diatas terlihat bahwa rata-rata skala nyeri haid responden sebelum pemberian dark chocolate dan obat anti nyeri adalah sebesar 4,81 dan kemudian setelah pemberian dark chocolate dan obat anti nyeri adalah sebesar 1,56. Dari hasil uji statistik wilcoxon didapatkan nilai $p$ value sebesar $0,000(p<0,05)$ maka secara statistik dapat disimpulkan bahwa terdapat perbedaan yang signifikan rata-rata intensitas nyeri haid sebelum dan sesudah pemberian dark chocolate dan obat anti nyeri. Hal ini dapat disimpulkan bahwa terjadi penurunan nilai rata-rata intensitas nyeri haid sebesar 3,25 pada responden sebelum dan sesudah pemberian dark chocolate dan obat anti nyeri.

Kemudian rata-rata skala nyeri haid responden pada kelompok kontrol sebelum diberikan obat anti nyeri haid adalah sebesar 4,50 dan kemudian setelah diberikan obat anti nyeri haid adalah sebesar 3,12. Dari hasil uji statistik wilcoxon didapatkan nilai $p$ value sebesar 0,001 $(p<0,05)$ maka secara statistik dapat disimpulkan bahwa terdapat perbedaan yang signifikan rata-rata intensitas nyeri haid pada kelompok kontrol sebelum dan sesudah diberikan obat anti nyeri haid. Hal ini dapat disimpulkan bahwa terjadi penurunan nilai rata-rata intensitas nyeri haid sebesar 1,38 pada kelompok kontrol sebelum dan sesudah diberikan obat anti nyeri haid.

Perbandingan rata-rata skala nyeri haid responden sebelum pemberian dark chocolate dan obat anti nyeri sebesar 4,81, sedangkan sebelum diberikan diberikan obat anti nyeri haid sebesar 4,50. Berdasarkan hasil uji statistik mann-whitney test antara sebelum pemberian dark chocolate dan obat anti nyeri dan sebelum diberikan obat anti nyeri haidsebesar 0,239 ( $p>0,05)$, maka secara statistik dapat disimpulkan tidak ada perbedaan penurunan intensitas nyeri haid responden sebelum diberikan dark chocolate + obat anti nyeri dan sebelum diberikan obat anti nyeri haid. Perebedaan intensitas nyeri haid diantara kelompok tersebut relatif kecil. Sehingga dapat disimpulkan bahwa nyeri haid antar dua kelompok pada keadaan yang setara. Artinya kalau terjadi penurunan nyeri haid (dismenorea) setelah diberikan perlakuan merupakan efek dari perlakuan pemberian dark chocolate + obat anti nyeri.

Perbandingan rata-rata skala nyeri haid responden setelah pemberian dark chocolate dan obat anti nyeri sebesar 1,56, sedangkan setelah diberikan obat anti nyeri haid sebesar 3,12. Berdasarkan hasil uji statistik mann-whitney test antara setelah pemberian dark chocolate dan obat anti nyeri, setelah diberikan obat anti nyeri haidsebesar 0,000 $(p<0,05)$ dan hasil uji statistik mann-whitney test pada rerata selisih skala nyeri haid antara kelompok diberikan dark chocolate dan obat anti nyeri, diberikan obat anti nyeri haid sebesar 0,000 ( $p<0,05)$, maka secara statistik dapat disimpulkan terdapat perbedaan penurunan intensitas nyeri haid antara kelompok diberikan dark chocolate dan obat anti nyeri, kelompok kontrol diberikan obat anti nyeri haid. Penurunan intensitas nyeri haid pada kelompok diberikan dark chocolate dan obat anti nyeri memiliki rata-rata lebih tinggi daripada kelompok diberikan obat anti nyeri haid, yaitu sebesar 3,25 dan pada kelompok diberikan obat anti nyeri haid sebesar 1,38. Sehingga dapat disimpulkan bahwa pemberian dark chocolate dan obat anti nyeri lebih berpengaruh dalam menurunkan intensitas nyeri haid dibandingkan dengan diberikan obat anti nyeri haid (kontrol). 
Tabel. 3

Penurunan Intensitas Nyeri Haid pada Intervensi Pemberian Massage Counterpressure Dibandingkan dengan Kelompok Kontrol

\begin{tabular}{|c|c|c|c|c|}
\hline \multirow[b]{2}{*}{$\begin{array}{l}\mathrm{N} \\
\mathrm{O}\end{array}$} & \multirow[b]{2}{*}{ Variabel Nyeri Haid } & \multicolumn{2}{|c|}{ Kelompok } & \multirow[b]{2}{*}{$p$ value } \\
\hline & & $\begin{array}{c}\text { Massage } \\
\text { counterpressure }(\mathrm{n}=16)\end{array}$ & $\begin{array}{l}\text { Kelompok Kontrol } \\
(\mathrm{n}=16)\end{array}$ & \\
\hline 1. & $\begin{array}{l}\text { Sebelum perlakuan } \\
\text { a. Mean } \pm \text { SD } \\
\text { b. Min-Maks } \\
\text { c. Median }\end{array}$ & $\begin{array}{c}4,75(0,683) \\
4 \pm 6 \\
5 \\
\end{array}$ & $\begin{array}{c}4,50(0,516) \\
4 \pm 5 \\
4,5 \\
\end{array}$ & 0,381 \\
\hline 2. & $\begin{array}{l}\text { Setelah Perlakuan } \\
\text { a. Mean } \pm \text { SD } \\
\text { b. Min-Maks } \\
\text { c. Median }\end{array}$ & $\begin{array}{c}3,12(0,619) \\
2 \pm 4 \\
3 \\
\end{array}$ & $\begin{array}{c}3,12(0,806) \\
2 \pm 4 \\
3 \\
\end{array}$ & 0,956 \\
\hline 3. & $\begin{array}{l}\text { Perbedaan nyeri } \\
\text { haid sebelum dan } \\
\text { sesudah perlakuan }\end{array}$ & & & \\
\hline & $p$ value $^{2}$ & 0,000 & 0,001 & - \\
\hline 4. & $\begin{array}{l}\text { Rerata Selisih } \\
\text { a. Mean } \pm \text { SD } \\
\text { b. Min-Maks } \\
\text { c. Median }\end{array}$ & $\begin{array}{c}1,62 \pm 0,619 \\
1-3 \\
2 \\
\end{array}$ & $\begin{array}{c}1,38 \pm 0,719 \\
0-2 \\
1,5 \\
\end{array}$ & 0,491 \\
\hline
\end{tabular}

Berdasarkan tabel 3 terlihat bahwa rata-rata skala nyeri haid responden sebelum pemberian massage counterpressure dan obat anti nyeri adalah sebesar 4,75 dan kemudian setelah pemberian massage counterpressure dan obat anti nyeri adalah sebesar 3,12. Dari hasil uji statistik wilcoxon didapatkan nilai $p$ value sebesar 0,000 ( $p<$ $0,05)$ maka secara statistik dapat disimpulkan bahwa terdapat perbedaan yang signifikan rata-rata intensitas nyeri haid sebelum dan sesudah pemberian massage counterpressure dan obat anti nyeri. Hal ini dapat disimpulkan bahwa terjadi penurunan nilai rata-rata intensitas nyeri haid sebesar 1,62 pada responden sebelum dan sesudah pemberian massage counterpressure dan obat anti nyeri.

Kemudian rata-rata skala nyeri haid responden pada kelompok kontrol sebelum diberikan obat anti nyeri haid adalah sebesar 4,50 dan kemudian setelah diberikan obat anti nyeri haid adalah sebesar 3,12. Dari hasil uji statistik wilcoxon didapatkan nilai $p$ value sebesar 0,001 $(p<0,05)$ maka secara statistik dapat disimpulkan bahwa terdapat perbedaan yang signifikan rata-rata intensitas nyeri haid pada kelompok kontrol sebelum dan sesudah diberikan obat anti nyeri haid. Hal ini dapat disimpulkan bahwa terjadi penurunan nilai rata-rata intensitas nyeri haid sebesar 1,38 pada kelompok kontrol sebelum dan sesudah diberikan obat anti nyeri haid.

Perbandingan rata-rata skala nyeri haid responden sebelum pemberian massage counterpressure dan obat anti nyeri sebesar 4,75, sedangkan sebelum diberikan diberikan obat anti nyeri haid sebesar 4,50. Berdasarkan hasil uji statistik mann-whitney test antara sebelum pemberian massage counterpressure dan obat anti nyeri dan sebelum diberikan obat anti nyeri haid sebesar 0,381 ( $p>0,05)$, maka secara statistik menunjukkan tidak ada perbedaan penurunan intensitas nyeri haid responden sebelum diberikan massage counterpressure dan obat anti nyeri dan sebelum diberikan obat anti nyeri haid. Perbedaan intensitas nyeri haid diantara kelompok tersebut relatif kecil. Sehingga dapat disimpulkan nyeri haid antar dua kelompok pada keadaan yang setara. Artinya kalau terjadi penurunan nyeri haid (dismenorea) setelah diberikan perlakuan merupakan efek dari perlakuan pemberian massage counterpressure dan obat anti nyeri. 
Perbandingan rata-rata skala nyeri haid responden setelah pemberian massage counterpressure dan obat anti nyeri sebesar 3,12, sedangkan setelah diberikan obat anti nyeri haid sebesar 3,12. Berdasarkan hasil uji statistik mann-whitney test antara setelah pemberian massage counterpressure dan obat anti nyeri dan setelah diberikan obat anti nyeri haidsebesar 0,956 ( $p>0,05)$ dan hasil uji statistik mann-whitney test pada rerata selisih skala nyeri haid antara kelompok diberikan massage counterpressure dan obat anti nyeri dan diberikan obat anti nyeri (kontrol) haid sebesar 0,491 ( $p>0,05)$, maka secara statistik dapat disimpulkan tidak terdapat perbedaan penurunan intensitas nyeri haid antara kelompok diberikan massage counterpressure dan obat anti nyeri dan diberikan obat anti nyeri haid (kontrol). Sehingga dapat disimpulkan bahwa pemberian massage counterpressure dan obat anti nyeri tidak berpengaruh dalam menurunkan intensitas nyeri haid.

Tabel. 4

Perbedaan Penurunan Nyeri Haid pada Kelompok Pemberian Dark Chocolate+Obat Anti nyeri dan Kelompok Tindakan Massage Counterpressure+Obat Anti Nyeri

\begin{tabular}{|c|c|c|c|c|}
\hline \multirow[b]{2}{*}{ No } & \multirow{2}{*}{$\begin{array}{l}\text { Variabel Nyeri } \\
\text { Haid }\end{array}$} & \multicolumn{2}{|c|}{ Kelompok } & \multirow[b]{2}{*}{$p$ value $^{1}$} \\
\hline & & $\begin{array}{l}\text { Dark Chocolate+obat } \\
\text { anti nyeri }(\mathrm{n}=16)\end{array}$ & $\begin{array}{c}\text { Massage counterpressure+obat } \\
\text { anti nyeri }(\mathrm{n}=16)\end{array}$ & \\
\hline \multirow[t]{5}{*}{1.} & Sebelum & & & \\
\hline & Perlakuan & & & \\
\hline & a. Mean $\pm \mathrm{SD}$ & $4,81(0,655)$ & $4,75(0,683)$ & 0,809 \\
\hline & b. Min-Maks & $4 \pm 6$ & $4 \pm 6$ & \\
\hline & c. Median & 5 & 5 & \\
\hline \multirow[t]{4}{*}{2.} & Setelah Perlakuan & & & \\
\hline & a. Mean \pm SD & $1,56(0,512)$ & $3,12(0,619)$ & ( \\
\hline & b. Min-Maks & $1 \pm 2$ & $2 \pm 4$ & 0,000 \\
\hline & c. Median & 2 & 3 & \\
\hline \multirow[t]{4}{*}{3.} & Perbedaan nyeri & & & \\
\hline & haid sebelum dan & & & \\
\hline & sesudah perlakuan & & & \\
\hline & $p$ value $^{2}$ & 0,000 & 0,000 & - \\
\hline \multirow[t]{4}{*}{4.} & Rerata Selisih & & & \\
\hline & a. Mean $\pm \mathrm{SD}$ & $3,25 \pm 0,775$ & $1,62 \pm 0,619$ & \\
\hline & b. Min-Maks & $2-4$ & $1-3$ & 0,000 \\
\hline & c. Median & 3 & 2 & \\
\hline
\end{tabular}

Perbandingan rata-rata skala nyeri haid responden sebelum pemberian dark chocolate dan obat anti nyeri sebesar 4,81, sebelum diberikan tindakan Massage counterpressure dan obat anti nyeri sebesar 4,75. Berdasarkan hasil uji statistik mannwhitney test antara sebelum pemberian dark chocolate dan obat anti nyeri dan sebelum tindakan massage counterpressure dan obat anti nyeri sebesar 0,809 ( $p>0,05)$, maka secara statistik dapat disimpulkan tidak ada perbedaan penurunan intensitas nyeri haid sebelum diberikan dark chocolate dan obat anti nyeri dan sebelum diberikan tindakan massage counterpressure dan obat anti nyeri. Perbedaan intensitas nyeri haid diantara kelompok tersebut relatif kecil. Sehingga dapat disimpulkan bahwa nyeri haid antar dua kelompok intervensi pada keadaan yang setara. Artinya terjadi penurunan nyeri haid setelah diberikan perlakuan merupakan efek dari perlakuan pemberian dark chocolate dan obat anti nyeri dan tindakan massage counterpressure dan obat anti nyeri. 
Perbandingan rata-rata skala nyeri haid setelah pemberian pada kelompok dark chocolate dan obat anti nyeri sebesar 1,56, dan pada kelompok tindakan massage counterpressure dan obat anti nyeri sebesar 3,12. Berdasarkan hasil uji statistik mannwhitney test antara setelah pemberian dua perlakuan sebesar $0,000(p<0,05)$ dan hasil uji statistik mann-whitney test pada rerata selisih skala nyeri haid antara kelompok pemberian dark chocolate dan obat anti nyeri dan diberikan tindakan massage counterpressure dan obat anti nyeri sebesar 0,001( $p<0,05)$, maka secara statistik dapat disimpulkan terdapat perbedaan penurunan intensitas nyeri haid antara kelompok diberikan dark chocolate dan obat anti nyeri dan diberikan tindakan massage counterpressure dan obat anti nyeri. Penurunan intensitas nyeri haid pada kelompok diberikan dark chocolate dan obat anti nyeriyaitu sebesar 3,25 dan pada kelompok tindakan massage counterpressure dan obat anti nyeri sebesar 1,62. Sehingga dapat disimpulkan bahwa pemberian dark chocolate dan obat anti nyeri lebih berpengaruh dalam menurunkan intensitas nyeri haid dibandingkan dengan diberikan tindakan massage counterpressure dan obat anti nyeri.

\section{PEMBAHASAN}

Hasil penelitian menunjukkan bahwa sebelum diberikan perlakuan, kedua kelompok tidak ada perbedaan intensitas nyeri haid, namun setelah diberikan perlakuan terdapat perbedaan yang signifikan penurunan intensitas nyeri haid antara kelompok intervensi dark chocolate dan kelompok intervensi massage counterpressure. Penurunan intensitas nyeri haid yang diberikan intervensi dark chocolate lebih tinggi dibandingkan dengan penurunan intensitas nyeri haid yang diberikan intervensi massage counterpressure sehingga dapat disimpulkan bahwa pemberian intervensi dark chocolate lebih efektif dalam menurunkan intensitas nyeri haid dibandingkan dengan intervensi massage counterpressure. Meskipun tingkat nyeri pada kedua kelompok intervensi sama-sama mengalami penurunan pada saat diberikan intervensi, akan tetapi penurunan intensitas nyeri haid yang lebih besar terjadi pada kelompok intervensi dark chocolate.

Dark chocolate atau cokelat hitam kaya akan kalsium, kalium, natrium, magnesium serta vitamin A, B1, C, D, dan E, Magnesium berguna untuk merelaksasikan otot dan dapat memberikan rasa rileks yang dapat mengendalikan suasana hati yang murung. Magnesium berfungsi untuk meringankan dismenorea atau rasa nyeri saat haid, magnesium memperbesar pembuluh darah sehingga bisa mencegah kejang otot dan dinding pembuluh darah dan magnesium bekerja untuk meringankan dismenore atau waktu menstruasi yang menyakitkan (Abdul Hanan \& Sindarti, 2015). Berdasarkan hasil penelitian ini bahwa coklat hitam lebih efektif dalam menurunkan nyeri haid dibandingkan dengan massage counterpressure. Hal ini dapat menjadi alternatif pilihan yang menyenangkan dalam penurunan, perlambatan, dan pencegahan intensitas nyeri haid sehingga dapat meminimalisir risiko dari kesalahan tekhnik massage counterpressure yang berakibat cedera atau bengkak pada bagian tubuh yang dipijat.

Pada kelompok massage counterpressure juga didapatkan pengaruh yang signifikan terhadap penurunan intensitas nyeri haid, pemberian massage counterpressure bertujuan untuk mengurangi rasa nyeri secara alamiah. Pemberian massage counterpressure pada daerah lumbal dapat menstimulasi serabut taktil di kulit sehingga sinyal nyeri haid dapat di hambat. Teknik counterpressure dapat menyebabkan peningkatan endorphine, yang dapat meredakan sakit secara alamiah. Counterpressure 
merupakan massage atau memijat dengan tekanan yang kuat yaitu meletakkan tangan atau bagian datar dari tangan, atau dapat menggunakan bola tenis. Counterpressure dapat diberikan dengan gerakan lurus atau lingkaran kecil yangdapat menutup gerbang pesan nyeri yang akan dihantar menuju medulla spinalis dan otak, selain itu dapat dihambat yang dapat menyebabkan penurunan intensitas nyeri (Deasyana \& Wagiyo, 2015).

Terapi massage counterpressure dapat di berikan pada pasien nyeri haid, terapi ini cukup efektif di berikan pada nyeri haid, karena pada saat muncul nyeri, syaraf yang menghantarkan nyeri akan di block sehingga tidak sampai ke pusat nyeri di otak. Dengan pemberian massage counterpressure dapat menutup gerbang pesan nyeri yang akan di hantarkan menuju medulla spinalis dan otak, selain itu tekanan kuat pada teknik ini dapat mengaktifkan senyawa endhorpine yang berada di sinaps sel-sel saraf tulang belakang dan otak, sehingga transmisi dari pesan nyeri dapat dihambat dan menyebabkan status penurunan sensasi nyeri. Gerakan dasar meliputi gerakan memutar, gerakan menekan dan mendorong kedepan dan belakang, menepuk-nepuk setiap gerakan menghasilkan efek yang diinginkan pada jaringan dibawahnya (Verawati, 2012).

\section{SIMPULAN}

Dark chocolate 100 gram selama 2 hari ditambah obat anti nyeri lebih efektif dibandingkan tindakan massage counterpressure 20 menit selama 2 hari ditambah obat anti nyeri terhadap intensitas nyeri haid.

\section{SARAN}

Berdasarkan hasil penelitian dan pembahasan dapat diberikan saran sebagai berikut:

Bagi remaja, tindakan alamiah massage counterpressure dan terapi non farmakologis dark chocolate alternatif untuk menurunkan intensitas nyeri haid. dark chocolate memilik keuntungan selain coklat yang mudah didapat, coklat juga merupakan salah satu makanan favorit bagi remaja, sedangkan massage counterpressure memiliki keuntungan bisa langsung diterapkan tetapi kurang efektif apabila tidak tepat pada bagian badan untuk mengurangi nyeri.

Bagi pihak sekolah dan bagi bidan, diharapkan memberikan informasi tentang terapi massage counterpressure dan dark chocolate untuk mengatasi penurunan nyeri haid dan dapat berperan aktif dalam mengatasi masalah remaja yang mengalami nyeri haid di sekolah.

Bagi peneliti, terapi massage counterpressure dan dark chocolate sebagai masukan bagi pengembangan ilmu kebidanan yang aplikatif, khususnya dalam penatalaksanaan penurunan nyeri haid remaja 


\section{DAFTAR PUSTAKA}

Abdul, H \& GM. Sindarti SM. (2015). Dark Chocolate dan nyeri Dysmenorhea. Jurnal Info Kesehatan Indonesia, 1-7

Azima, S., Bakhsayesh, R. H., Keramatollah, A., Maasumeh, K., Sayadi. (2015). Effect of Isometric Exercise on Promary Dysmenorhea: A Randomized Controlled Clinical Trial. Galen Medical Journal, 4(1), 26-32

Deasyana, P., Wagiyo U. N. (2015). Perbedaan Efektifitas Tehnik Counterpressure dan Kompres Hangat terhadap Penurunan Nyeri Persalinan Kala 1 Fase Aktif. Jurnal Ilmu Keperawatan dan Kebidanan

Susilawati. (2009). Perbedaan Efektivitas Susu dan Cokelat terhadap Penurunan Skala Nyeri pada Remaja Putri Dismenore di SMAN 1 Ungaran. 1-13

Verawati S. (2012). Merawat dan Menjaga Kesehatan Seksual Wanita. Bandung: Gravindo. 46-55 